\title{
PREVALENSI DAN DISTRIBUSI OSTEOARTRITIS LUTUT BERDASARKAN KARAKTERISTIK SOSIO-DEMOGRAFI DAN FAKTOR RISIKO DI WILAYAH KERJA PUSKESMAS SUSUT I, KECAMATAN SUSUT, KABUPATEN BANGLI PADA TAHUN 2014
}

\author{
Wan Amin Hasiibi Bin Wan Ali ${ }^{1}$ \\ ${ }^{1}$ Pendidikan Dokter, Fakultas Kedokteran, Universitas Udayana \\ (aminhasiibi@yahoo.com)
}

ABSTRAK

Terjadinya proses penuaan akan meningkatkan jumlah angka kesakitan akibat penyakit degeneratif dan disabilitas yang ditimbulkan. Di Poliklinik Reumatologi RSUP Sanglah Denpasar periode 2001-2002, OA merupakan kasus tertinggi (37\%) dengan proporsi Osteoartritis (OA) lutut 97\%. Di Puskesmas Susut I, Kecamatan Susut, Kabupaten Bangli, OA yang tergolong ke dalam kelompok penyakit rematik menempati urutan kedua di daftar penyakit Puskesmas Susut I tahun 2013.

Metode rancangan dalam penelitian ini adalah cross sectional deskriptif. Sampel penelitian merupakan penduduk usia 50 tahun ke atas dengan besar sampel yang digunakan adalah 78 orang dengan teknik multistage random sampling di Banjar Susut Kaja, Desa Susut, Kecamatan Susut, Kabupaten Bangli pada bulan April 2014.

Hasil dan simpulan penelitian ini adalah prevalensi OA lutut pada usia $>50$ tahun di Desa Susut bulan April 2014 adalah sebesar 62.8\%. Berdasarkan karakteristik sosio-demografi, kejadian OA lutut lebih banyak dialami oleh kelompok usia 50-70 tahun (61.2\%), berjenis kelamin perempuan (57.1\%), dan memiliki pekerjaan fisik (petani, peternak, buruh dan ABRI) (65.3\%). Sedangkan berdasarkan faktor risiko, kejadian OA lutut lebih banyak terjadi pada responden dengan IMT kurus-normal (59.2\%), riwayat beban kerja sedang-berat (71.4\%) dengan faktor biomekanika antara lain responden dengan riwayat membawa beban saat bekerja (71.4\%) dimana perkiraan berat beban $<25 \mathrm{~kg}$ (79.6\%), frekuensi bekerja dengan beban sebanyak $\geq 4 \mathrm{kali} / \mathrm{minggu}$ (53.1\%) dan memiliki durasi kerja $\geq 17$ tahun (91.8\%), serta menempuh jalan naik, turun, bertangga saat bekerja (77.6\%). Kejadian OA lutut lebih banyak terjadi pada responden tanpa riwayat cedera lutut (87.8\%).

Kata Kunci : Prevalensi, faktor risiko, osteoartritis lutut, usia lanjut

\section{PREVALENCE AND DISTRIBUTION OF KNEE OSTEOARTHRITIS ACCORDING TO SOCIO-DEMOGRAPHY CHARACTERISTIC AND RISK FACTOR IN SUSUT I PRIMARY HEALTH CARE TERRITORY, SUSUT, BANGLI IN 2014}

\section{ABSTRACT}

An aging process will increase human morbidity caused by degenerative diseases and disability. Based on data in Policlinic of Rheumatology Sanglah Hospital in 2001-2002, Osteoarthritis was the highest case (37\%) with proportion of Knee Osteoarthritis was 97\%. In Susut I Primary Health Care, which is located in Bangli, Rheumatic placed the second rank from the list of top 10 diseases in 2013.

This research used cross sectional descriptive method. Sample were elderly who are more than 50 years old and total of sample was 78 which are taken by multistage random sampling method from Banjar Susut Kaja, Susut Village, Susut Subdisctric, Bangli Regency, April 2014. 
The prevalence of Knee Osteoarthritis in elderly who are more than 50 years old in Susut Village in April 2014 was 62,8\%. According to socio-demography characteristic, knee osteoarthritis occured more in respondents who are 50-70 years old (61.2\%), women (57.1\%), and had physical job (farmer, cattleman, labor and army) (65.3\%). While, according to risk factors, knee osteoarthritis occured more in respondents who had underweight-normal body mass index (59.2\%), with history of workload due to medium-hard (71.4\%), with biomechanics factors where respondents who bring goods while worked (71.4\%), and the weight of goods estimated more than $25 \mathrm{~kg}$ (79.6\%), work frequencies with goods more than 4 times a week (53.1\%), respondents who had work duration more than 17 years $(91.8 \%)$, and respondents who had up and down pathway and also using stairs (77.6\%). Knee osteoarthritis occured more in respondents without history of knee trauma (87.8\%).

Keywords: Prevalence, risk factor, knee osteoarthritis, elderly

\section{PENDAHULUAN}

Seiring dengan pembangunan nasional yang berkembang pesat terutama di bidang kesehatan, kualitas kesehatan penduduk juga meningkat dan berdampak pada tingginya Usia Harapan Hidup (UHH) manusia.Menurut Badan Pusat Statistik (BPS), Indonesia termasuk Negara berstruktur tua dimana hal ini dapat dilihat dari jumlah penduduk lansia pada tahun 2008, 2009 dan 2012 telah mencapai di atas 7\% dari keseluruhan penduduk. Secara global diprediksi populasi lansia di Indonesia akan terus mengalami peningkatan. ${ }^{1}$ Meskipun bukan suatu penyakit, namun bersamaan dengan proses penuaan dan tingginya UHH maka akan meningkatkan jumlah angka kesakitan akibat penyakit degeneratif dan disabilitas yang diakibatkan.

Osteoartritis (OA) merupakan penyakit sendi degeneratif yang ditandai oleh kehilangan tulang rawan sendi secara perlahan, berkombinasi dengan penebalan tulang subkondral dan terbentuk osteofit pada tepi sendi, serta peradangan nonspesifik sinovium yang ringan. ${ }^{2,3} \mathrm{OA}$ biasa mengenai sendi yang menopang berat badan seperti lutut, panggul, tulang belakang dan kaki. OA berperan penting sebagai penyebab utama nyeri dan disabilitas pada lansia. ${ }^{4}$

Berdasarkan hasil penelitian Zeng QY et al, prevalensi OA di Indonesia mencapai 23,6 sampai 31,3\% dan diperkirakan 1-2 juta lansia menderita cacat akibat OA. ${ }^{3,5}$ Sedangkan berdasarkan penelitian Arissa MI tahun 2008-2009, angka kejadian tertinggi OA ditemukan pada usia $>55$ tahun $(59,17 \%)$ dari keseluruhan kasus OA di RSU Dokter Soedarso Pontianak. ${ }^{6}$ Disamping itu, usia di atas 50 tahun merupakan salah satu kriteria klinis dalam mendiagnosis OA berdasarkan kriteria American College of Rheumatology (ACR) tahun 1986. Di Poliklinik Reumatologi RSUP Sanglah Denpasar periode 20012002, OA merupakan kasus tertinggi (37\%) dari semua kasus rematik dimana dari keseluruhan penderita OA tersebut proporsi dari OA lutut adalah sebesar $97 \% .^{5}$

Data penderita OA lutut di Puskesmas Susut I, Kecamatan Susut, Kabupaten Bangli sendiri belum diketahui dengan pasti. Berdasarkan rekapitulasi data masing-masing puskesmas pembantu disebutkan bahwa rematik merupakan penyakit di urutan kedua yaitu sebanyak 1.486 kasus (16\%) dari 10 besar penyakit di wilayah kerja Puskesmas Susut I. Data ini belum merepresentasikan jumlah seluruh penderita karena data tersebut hanya diperoleh dari penderita yang datang ke puskesmas untuk mencari pengobatan dengan keluhan nyeri sendi. ${ }^{7}$

Penyebab primer dari OA masih belum dapat diketahui secara pasti namun terdapat beberapa faktor risiko yang berperan yaitu: usia, jenis kelamin, genetik, kegemukan dan penyakit metabolik, cedera sendi, pekerjaan dan olahraga, kelainan pertumbuhan serta faktor-faktor lainnya. Faktor-faktor tersebut dapat dikelompokkan menjadi faktor-faktor yang mempengaruhi predisposisi generalisata dan faktorfaktor yang menyebabkan beban biomekanik tak normal pada sendi-sendi tertentu. ${ }^{2}$

Di wilayah kerja Puskesmas Susut I yang merupakan wilayah dataran tinggi, sebagian besar penderita nyeri sendi yang datang ke adalah penduduk lansia dengan mata pencaharian sebagai petani. ${ }^{7}$ Kondisi geografis yang merupakan dataran tinggi disertai dengan pekerjaan dengan beban kerja yang berat dapat menjadi suatu faktor predisposisi terjadinya OA lutut. ${ }^{4}$ 
Berdasarkan uraian di atas perlu dilakukan suatu penelitian mengenai prevalensi dan distribusi OA lutut berdasarkan faktor risiko di wilayah kerja Puskesmas Susut I, Kecamatan Susut, Kabupaten Bangli pada kelompok usia di atas 50 tahun sehingga dapat diperoleh gambaran mengenai OA lutut pada lansia di wilayah kerja Puskesmas Susut I sebagai langkah pertama dalam penentuan usaha promotif dan preventif dalam menghadapi permasalahan lansia khususnya mengenai penyakit OA lutut.

\section{METODE PENELITIAN}

\section{Tempat dan Waktu Penelitian}

Penelitian ini dilakukan di wilayah kerja

Puskesmas Susut I, Kecamatan Susut, Kabupaten Bangli pada bulan April 2014.

\section{Rancangan Penelitian}

Penelitian ini menggunakan rancangan penelitian cross sectional deskriptif yaitu dilakukan satu kali pengumpulan data untuk memperoleh gambaran berbagai faktor yang terkait dengan osteoartritis (OA) lutut di wilayah kerja Puskesmas Susut I.

\section{Populasi Penelitian}

Populasi dalam penelitian ini adalah seluruh penduduk berusia di atas 50 tahun yang berlokasi di wilayah kerja Puskesmas Susut I, Kecamatan Susut, Kabupaten Bangli. Terdapat 5 desa yang termasuk ke dalam wilayah kerja Puskesmas Susut I yaitu Desa Tiga, Desa Penglumbaran, Desa Susut, Desa Selat dan Desa Demulih. Jumlah penduduk berusia di atas 50 tahun di seluruh wilayah kerja Puskesmas Susut I ini adalah sebanyak 3.120 orang.

\section{Kriteria Inklusi dan Eksklusi}

Kriteria Inklusi sampel adalah seluruh penduduk di wilayah kerja Puskesmas Susut I yang berusia 50 tahun ke ataspada bulan April 2014 yang berdomisili di wilayah Puskesmas Susut I, Kecamatan Susut, Kabupaten Bangli yang bersedia mengikuti penelitian dengan memberikan persetujuan secara lisan.Kriteria eksklusi yaitu tidak mampu diwawancarai disebabkan kondisi medis umum yang tidak memungkinkan.

\section{Sampel Penelitian}

Dari hasil perhitungan maka diperoleh besar sampel minimal sebesar 78. Teknik pengambilan sampel yaitu dengan Sampel dipilih dengan metode multistage random samplingdengan pertimbangan cakupan wilayah kerja Puskesmas Susut I yang luas, jumlah penduduk lansia yang banyak dan homogen serta terbatasnya dana penelitian.

Sampel adalah kelompok penduduk yang usianya lebih dari 50 tahun yang kemudian ditetapkan sebagai responden dalam memperoleh informasi mengenai hal-hal terkait variabel penelitian.

\section{Variabel Penelitian}

Variabel dalam penelitian ini adalah:Kejadian OA pada lansia, karakteristik sosio-demografi (umur, jenis Kelamin, pekerjaan), Faktor risiko (Indeks Masa Tubuh, Riwayat Beban Kerja, Faktor Biomekanik).

\section{Analisa Data}

Analisa data dilakukan secara deskriptif dengan melihat distribusi jawaban responden terhadap masingmasing pertanyaan. Kemudian disajikan dalam bentuk naratif atau tabel (persentase).

\section{HASIL}

\section{Karakteristik Responden}

Dari 78 responden yang berpartisipasi dalam penelitian ini, diperoleh karakteristik sosio-demografi responden yang meliputi umur, jenis kelamin dan jenis pekerjaan seperti yang terlihat pada tabel 1 .

Berdasarkan tabel 1, kelompok usia terbanyak responden adalah kelompok usia 60 - 69 tahun. Ratarata usia responden secara keseluruhan adalah $67.40 \pm$ 1.165 tahun (median 66.50 tahun) dengan usia minimal adalah 52 tahun dan usia maksimal 91 tahun. Proporsi responden berjenis kelamin laki-laki hampir sebanding dengan perempuan (masing-masing $47.4 \%$ dan $52.6 \%$ ). Sebagian besar responden bekerja sebagai petani dan peternak (34.6\%) serta buruh (20.5\%).

\section{Prevalensi Osteoartritis (OA) Lutut}

Point Prevalensi OA lutut pada penelitian ini ditentukan melalui krineria klinis ACR tahun 1986 seperti yang dapat dilihat pada tabel 2.

Dari tabel 2, didapatkan bahwa point prevalensi OA lutut pada penduduk usia di atas 50 tahun di Desa Susut Kecamatan Susut Kabupaten Bangli pada bulan April 2014 sebesar $62.8 \%$.

\section{Faktor Risiko OA Lutut}

Berdasarkan tabel 3, proporsi responden memiliki Indeks Masa Tubuh (IMT) kurus - normal lebih banyak daripada responden yang memiliki IMT berisiko OA lutut (masing-masing 57.7\% dan 42.3\%). Sebagian besar responden (66.7\%) memiliki riwayat beban kerja sedang-berat. 
Tabel 1. Karakteristik Sosio-demografi

\begin{tabular}{llll}
\hline VARIABEL & KATEGORI & F & \% \\
\hline Usia & $50-59$ & 22 & 28.2 \\
& $60-69$ & 27 & 34.6 \\
& $70-79$ & 17 & 21.8 \\
& $80-89$ & 11 & 14.1 \\
& $\geq 90$ & 1 & 1.3 \\
\hline Total & & 78 & 100 \\
\hline Jenis Kelamin & Laki-laki & 37 & 47.4 \\
& Perempuan & 41 & 52.6 \\
\hline Total & & 78 & 100 \\
\hline Pekerjaan & Petani dan Peternak & 27 & 34.6 \\
& Buruh & 16 & 20.5 \\
& PNS & 15 & 19.2 \\
& IRT & 10 & 12.8 \\
& Wiraswasta & 6 & 7.7 \\
& ABRI & 4 & 5.1 \\
\hline Total & & 78 & 100 \\
\hline
\end{tabular}

Sebagian besar responden membawa beban saat bekerja (65.4\%) dengan perkiraan beban terbanyak $<25 \mathrm{~kg}(83.3 \%)$. Frekuensi bekerja dengan beban dalam seminggu terbanyak adalah $<4 x /$ minggu (58.4\%) dengan durasi kerja dalam tahun terbanyak $\geq 17$ tahun (89.7\%). Sebagian besar kondisi geografis yang ditempuh responden adalah naik-turun dan tangga (71.8\%). Dan sebagian besar responden tidak pernah mengalami cedera lutut sebelumnya (89.7\%).

\section{Distribusi OA Lutut Berdasarkan Karakteristik Sosio- demografi}

Dari tabel 4 dapat dilihat bahwa kejadian OA lutut lebih banyak dialami oleh kelompok usia 50-70 tahun (61.2\%), pada perempuan (57.1\%) dan pada pekerja fisik (petani, buruh, ABRI dan peternak) (65.3\%).

Dari tabel 5 dapat dilihat bahwa $70.4 \%$ responden berusia > 70 tahun menderita OA lutut.
Dilihat dari jenis kelamin dan pekerjaan, sebesar $68.3 \%$ responden perempuan dan $68.1 \%$ pekerja fisik menderita OA lutut.

\section{Distribusi OA Lutut Berdasarkan Faktor Risiko}

Berdasarkan tabel 6, proporsi kejadian OA pada responden dengan IMT kurus-normal sedikit lebih banyak (59.2\%) daripada responden yang kelebihan berat badan-kegemukan. Sebagian besar kejadian OA lutut dialami oleh responden yang riwayat beban kerjanya sedang-berat (71.4\%) dengan perkiraan berat beban < $25 \mathrm{~kg}$ (79.6\%) dan frekuensi kerja dengan beban dalam minggu $\geq 4 \mathrm{x} /$ minggu. Sebagian besar kejadian $\mathrm{OA}$ lutut dialami responden dengan durasi kerja $\geq 17$ tahun (91.8\%) dengan kondisi geografis yang naik-turun dan tangga (77.6\%). Dan sebagian besar kejadian OA dialami oleh responden yang tidak pernah mengalami cedera lutut sebelumnya (87.8\%).

Tabel 2. Prevalensi OA Lutut

\begin{tabular}{llll}
\hline VARIABEL & KATEGORI & F & \% \\
\hline Osteoartritis Lutut & Ya & 49 & 62.8 \\
& Tidak & 29 & 37.2 \\
\hline Total & & 78 & 100 \\
\hline
\end{tabular}


Tabel 3. Faktor Risiko OA Lutut

\begin{tabular}{|c|c|c|c|}
\hline VARIABEL & KATEGORI & $\mathbf{F}$ & $\%$ \\
\hline \multirow[t]{2}{*}{ Indeks Masa Tubuh } & Kurus - Normal & 45 & 57.7 \\
\hline & $\begin{array}{l}\text { Kelebihan Berat Badan - } \\
\text { Kegemukan }\end{array}$ & 33 & 42.3 \\
\hline Total & & 78 & 100 \\
\hline \multirow[t]{3}{*}{ Riwayat Beban Kerja } & Beban Kerja Ringan & 26 & 33.3 \\
\hline & Beban Kerja Sedang - & 52 & 66.7 \\
\hline & Berat & & \\
\hline Total & & 78 & 100 \\
\hline \multicolumn{4}{|l|}{ Faktor Biomekanika } \\
\hline \multirow[t]{2}{*}{ Riwayat Membawa Beban } & $\mathrm{Ya}$ & 51 & 65.4 \\
\hline & Tidak & 27 & 34.6 \\
\hline Total & & 78 & 100 \\
\hline \multirow[t]{2}{*}{ Perkiraan Berat Beban } & $<25 \mathrm{~kg}$ & 65 & 83.3 \\
\hline & $\geq 25 \mathrm{~kg}$ & 13 & 16.7 \\
\hline Total & & 78 & 100 \\
\hline Frekuensi $\quad$ Kerja dengan & $<4$ & 44 & 58.4 \\
\hline \multirow[t]{2}{*}{ Beban dalam Minggu } & $\geq 4$ & 34 & 43.6 \\
\hline & & 78 & 100 \\
\hline \multirow[t]{2}{*}{ Durasi Kerja dalam Tahun } & $<17$ & 8 & 10.3 \\
\hline & $\geq 17$ & 70 & 89.7 \\
\hline Total & & 78 & 100 \\
\hline Kondisi Geografi Saat & Naik-Turun dan Tangga & 56 & 71.8 \\
\hline \multirow[t]{2}{*}{ Bekerja } & Datar & & \\
\hline & & 22 & 28.2 \\
\hline Total & & 78 & 100 \\
\hline \multirow[t]{2}{*}{ Riwayat Cedera Lutut } & $\mathrm{Ya}$ & 8 & 10.3 \\
\hline & Tidak & 70 & 89.7 \\
\hline Total & & 78 & 100 \\
\hline
\end{tabular}

Tabel 4. Distribusi OA Lutut Berdasarkan Karakteristik Sosio-demografi

\begin{tabular}{|c|c|c|c|c|c|c|c|}
\hline \multirow{2}{*}{\multicolumn{2}{|c|}{ Karakteristik Sosio-demografi }} & \multicolumn{4}{|c|}{ Osteoartritis Lutut } & \multirow{3}{*}{$\begin{array}{l}\text { Total } \\
51\end{array}$} & \multirow{3}{*}{$\begin{array}{l}\% \\
65.4\end{array}$} \\
\hline & & \multirow{2}{*}{$\begin{array}{l}\mathrm{Ya} \\
30\end{array}$} & \multirow{2}{*}{$\begin{array}{l}\% \\
61.2\end{array}$} & \multirow{2}{*}{$\begin{array}{l}\text { Tidak } \\
21\end{array}$} & \multirow{2}{*}{$\begin{array}{l}\% \\
72.4\end{array}$} & & \\
\hline Usia & $50-70$ & & & & & & \\
\hline & $>70$ & 19 & 38.8 & 8 & 27.6 & 27 & 34.6 \\
\hline Total & & 49 & 100 & 29 & 100 & 78 & 100 \\
\hline \multirow[t]{2}{*}{ Jenis Kelamin } & Laki-laki & 21 & 42.9 & 16 & 55.2 & 37 & 47.4 \\
\hline & Perempuan & 28 & 57.1 & 13 & 44.8 & 41 & 52.6 \\
\hline Total & & 49 & 100 & 29 & 100 & 78 & 100 \\
\hline \multirow[t]{2}{*}{ Pekerjaan } & Pekerja Fisik & 32 & 65.3 & 15 & 51.7 & 47 & 60.3 \\
\hline & Pekerja Non Fisik & 17 & 34.7 & 14 & 48.3 & 31 & 39.7 \\
\hline Total & & 49 & 100 & 29 & 100 & 78 & 100 \\
\hline
\end{tabular}


ISSN: 2089-9084

ISM, VOL. 4 NO.1, SEPTEMBER-DESEMBER, HAL 32-41

Tabel 5. Kecenderungan Kejadian OA Lutut Berdasarkan Karakteristik Sosio-demografi

\begin{tabular}{llllllll}
\hline \multirow{2}{*}{ Karakteristik Sosio-demografi } & \multicolumn{3}{c}{ Osteoartritis Lutut } & \multirow{2}{*}{ Total } & \multirow{2}{*}{$\%$} \\
\cline { 2 - 6 } & & Ya & $\%$ & Tidak & $\%$ & & \\
\hline Usia & $50-70$ & 30 & 58.8 & 21 & 41.2 & 51 & 100 \\
& $>70$ & 19 & 70.4 & 8 & 29.6 & 27 & 100 \\
\hline Jenis Kelamin & Laki-laki & 21 & 56.8 & 16 & 43.2 & 37 & 100 \\
& Perempuan & 28 & 68.3 & 13 & 31.7 & 41 & 100 \\
\hline Pekerjaan & Pekerja Fisik & 32 & 68.1 & 15 & 31.9 & 47 & 100 \\
& Pekerja Non Fisik & 17 & 54.8 & 14 & 45.2 & 31 & 100 \\
\hline
\end{tabular}

Tabel 6. Distribusi OA Lutut Berdasarkan Faktor Risiko

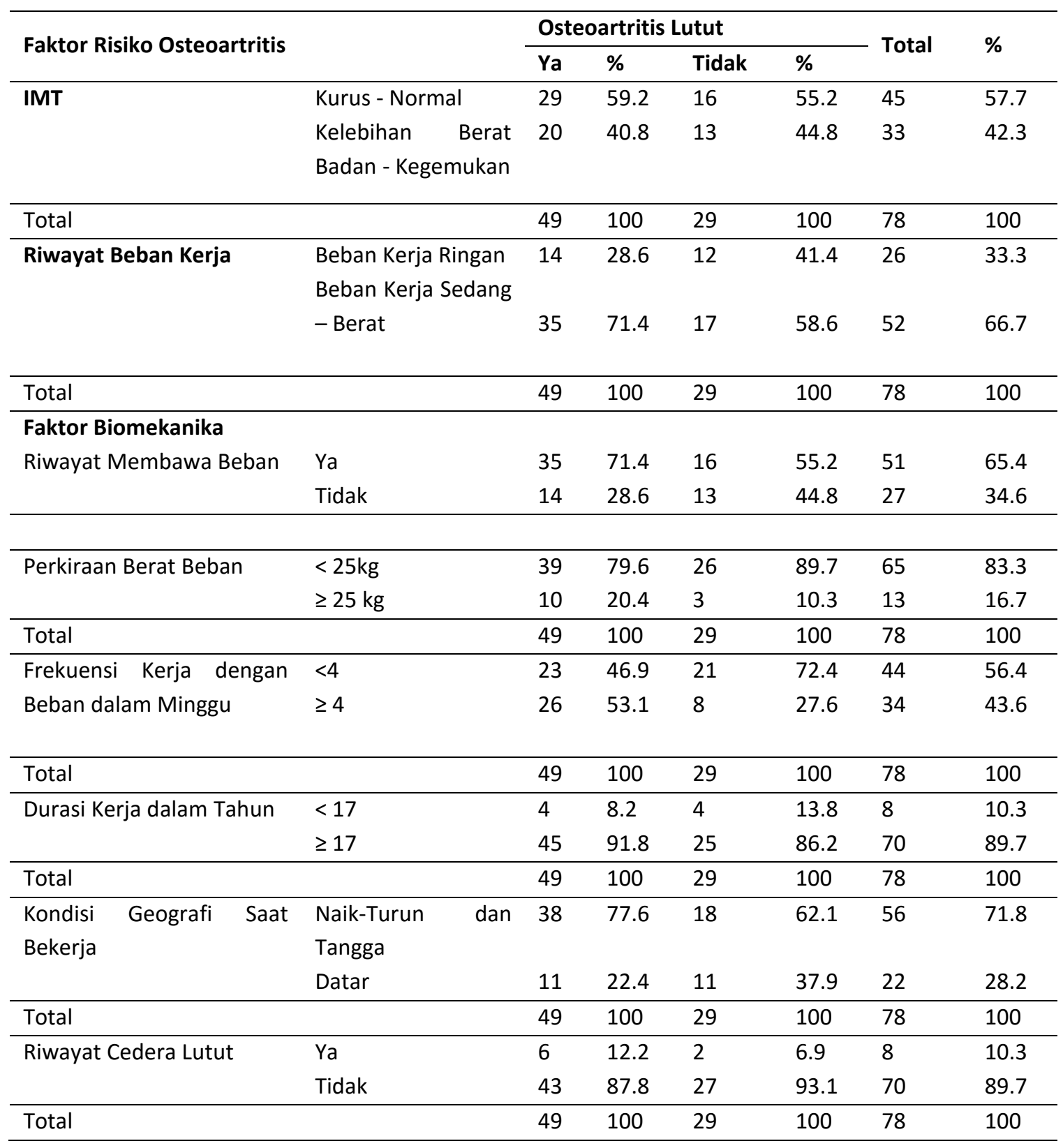


Tabel 7. Kecenderungan Kejadian OA Lutut Berdasarkan Faktor Risiko

\begin{tabular}{|c|c|c|c|c|c|c|c|}
\hline \multirow[t]{2}{*}{ Faktor Risiko Osteoartritis } & & \multicolumn{4}{|c|}{ Osteoartritis Lutut } & \multirow{2}{*}{ Total } & \multirow{2}{*}{$\%$} \\
\hline & & $\mathrm{Ya}$ & $\%$ & Tidak & $\%$ & & \\
\hline \multirow[t]{3}{*}{ IMT } & Kurus - Normal & 29 & 64.4 & 16 & 35.6 & 45 & 100 \\
\hline & Kelebihan Berat & 20 & 60.6 & 13 & 39.4 & 33 & 100 \\
\hline & Badan - Kegemukan & & & & & & \\
\hline \multirow[t]{3}{*}{ Riwayat Beban Kerja } & Beban Kerja Ringan & 14 & 53.8 & 12 & 46.2 & 26 & 100 \\
\hline & Beban Kerja Sedang & & & & & & \\
\hline & - Berat & 35 & 67.3 & 17 & 32.7 & 52 & 100 \\
\hline \multicolumn{8}{|l|}{ Faktor Biomekanika } \\
\hline \multirow[t]{2}{*}{ Riwayat Membawa Beban } & $\mathrm{Ya}$ & 35 & 68.6 & 16 & 31.4 & 51 & 100 \\
\hline & Tidak & 14 & 51.9 & 13 & 48.1 & 27 & 100 \\
\hline \multirow[t]{2}{*}{ Perkiraan Berat Beban } & $<25 \mathrm{~kg}$ & 39 & 60.0 & 26 & 40.0 & 65 & 100 \\
\hline & $\geq 25 \mathrm{~kg}$ & 10 & 76.9 & 3 & 23.1 & 13 & 100 \\
\hline Frekuensi Kerja dengan & $<4$ & 23 & 52.3 & 21 & 47.7 & 44 & 100 \\
\hline Beban dalam Minggu & $\geq 4$ & 26 & 76.5 & 8 & 26.9 & 34 & 100 \\
\hline \multirow[t]{2}{*}{ Durasi Kerja dalam Tahun } & $<17$ & 4 & 50.0 & 4 & 50.0 & 8 & 100 \\
\hline & $\geq 17$ & 45 & 64.3 & 25 & 35.7 & 70 & 100 \\
\hline \multirow{3}{*}{$\begin{array}{l}\text { Kondisi } \\
\text { Bekerja }\end{array}$} & Naik-Turun & 38 & 67.9 & 18 & 32.1 & 56 & 100 \\
\hline & Tangga & & & & & & \\
\hline & Datar & 11 & 50.0 & 11 & 50.0 & 22 & 100 \\
\hline \multirow[t]{2}{*}{ Riwayat Cedera Lutut } & $\mathrm{Ya}$ & 6 & 75 & 2 & 25 & 8 & 100 \\
\hline & Tidak & 43 & 61.4 & 27 & 38.6 & 70 & 100 \\
\hline
\end{tabular}

Berdasarkan tabel 7, 64.4\% responden dengan IMT kurus-normal menderita OA lutut. Angka ini sedikit lebih banyak dari proporsi responden dengan IMT kelebihan berat badan-kegemukan yang menderita OA lutut (60.6\%). Dilihat dari riwayat beban kerja, 67.3\% responden dengan beban kerja sedang-berat menderita OA lutut.

Berdasarkan faktor biomekanika, $68.6 \%$ responden dengan riwayat membawa beban saat bekerja, $76.9 \%$ responden yang membawa beban $\geq 25$ $\mathrm{kg}, 76.5 \%$ responden yang bekerja dengan beban $\geq 4 \mathrm{x}$ dalam seminggu dan $64.3 \%$ responden yang bekerja $\geq 17$ tahun menderita OA lutut. Berdasarkan kondisi geografis saat bekerja, $67.9 \%$ responden yang kondisi geografis kerjanya naik-turun dan tangga menderita OA lutut. Sebanyak $75 \%$ responden yang pernah mengalami cedera lutut menderita OA lutut.

\section{PEMBAHASAN}

\section{Prevalensi Osteoartritis (OA) Lutut}

Dari penelitian ini ditemukan responden yang memiliki OA lutut di Desa Susut Kecamatan Susut Kabupaten Bangli pada penduduk usia 50 tahun ke atas adalah 49 orang (62.8\%). Angka ini sedikit lebih tinggi dari prevalensi OA pada kelompok usia di atas 60 tahun di Desa Serampingan, Tabanan tahun 2012 pada penelitian Dwipayana G A et al yaitu sebesar $57 \%{ }^{3}$

\section{Distribusi OA Lutut Berdasarkan Usia}

OA merupakan penyakit degeneratif sendi yang sangat erat kaitannya dengan usia. Prevalensi OA cukup tinggi di kalangan lansia dimana salah satu dari kriteria diagnosis klinis American College of Reumatology (ACR) 1986 adalah usia di atas 50 tahun.Pada usia lanjut, terjadi perubahan kolagen dan penurunan sintesis proteoglikan yang menyebabkan tulang dan sendi lebih 
rentan terhadap tekanan dan kekurangan elastisitas sendi. Sampel yang digunakan pada penelitian ini diambil dari kelompok usia di atas 50 tahun yang memang sudah memiliki faktor risiko untuk menderita OA dimana menurut konsep teori prevalensi dan beratnya OA semakin meningkat dengan bertambahnya usia seseorang.

Dari hasil penelitian, kelompok usia terbanyak yang mengalami OA adalah kelompok usia 50-70 tahun (61.2\%). Hal ini sejalan dengan penelitian Arissa Ml et al di RSU dr. Soedarso Pontianak tahun 2012 dimana proporsi kasus OA terbanyak dialami kelompok usia 5572 tahun. Berdasarkan hasil penelitian di Desa Serampingan, Tabanan tahun 2012 prevalensi OA paling banyak didapatkan pada kelompok usia 60-70 tahun (63.1\%). Dilihat dari kecenderungan kejadian OA, sebanyak $70.4 \%$ responden yang berusia di atas 70 tahun menderita OA lutut. Angka ini lebih banyak jika dibandingkan jumlah penderita OA lutut pada kelompok usia 50 - 70 tahun (58.8\%). Berdasarkan hasil di atas, terlihat adanya kecenderungan peningkatan prevalensi OA seiring dengan bertambahnya usia responden. ${ }^{2,3,6}$

Desa Susut merupakan wilayah cakupan dari Puskesmas Susut I dimana terdapat program kesehatan usila (usia lanjut) sebagai salah satu program pengembangan yang masih berjalan kurang efektif. Melihat tingginya angka prevalensi OA lutut di Desa Susut pada kelompok usia lanjut maka perlu diadakan suatu intervensi terhadap kelompok ini dalam rangka menghentikan progresivitas penyakit OA lutut yang dapat berdampak pada disabilitas lansia.

\section{Distribusi OA Lutut Berdasarkan Jenis Kelamin}

Pada penelitian ini didapatkan kejadian OA lebih banyak pada perempuan (57.1\%) daripada laki-laki (42.9\%) dimana kejadian OA lutut pada perempuan adalah sebanyak 68.3\%. Angka ini lebih banyak daripada kejadian OA lutut pada laki-laki (56.8\%). Dari angka tersebut dapat dilihat bahwa kejadian OA cenderung dialami oleh perempuan. Hal ini sejalan dengan konsep teori yang menyatakan bahwa secara keseluruhan pada usia di atas 50 tahun, frekuensi OA lebih banyak terjadi pada wanita (setelah menopause) yang menunjukkan faktor hormonal yang turut berperan pada kejadian OA. Hasil tersebutjuga sejalan dengan penelitian di RSU dr. Soedarso Pontianak dimana proporsi kasus OA terbanyak terjadi pada wanita (68.67\%) dan penelitian
Maharani E P dimana jenis kelamin perempuan dinyatakan sebagai salah satu faktor risiko terjadinya $\mathrm{OA}$ di $(p=0,043 ; O R=2,14) .3,6,10$

Melihat tingginya kejadian OA pada wanita maka perlu dilakukan suatu penyuluhan kepada kelompok wanita di Desa Susut misalnya melalui program KIA KB/ penyuluhan terhadap ibu-ibu PKK mengenai bahaya OA terhadap perempuan pasca menopause dan faktor risiko lainnya.

\section{Distribusi OA Lutut Berdasarkan Jenis Pekerjaan}

Berdasarkan jenis pekerjaan, OA lutut paling banyak terjadi pada pekerja fisik (petani, buruh, ABRI dan peternak) (65.3\%) dimana sebanyak 68.1\% pekerja fisik (petani, peternak, buruh dan ABRI) menderita $O A$ lutut. Hasil ini juga sejalan dengan penelitian Dwipayana G A, angka kejadian OA di kalangan petani adalah sebesar $57 \% .{ }^{3}$ Dapat dilakukan suatu edukasi kepada kelompok pekerja fisik bagaimana mengurangi beban kerja dan aktivitas apa saja yang dapat berisiko terjadinya OA serta kegiatan pencegahan yang dapat dilakukan.

\section{Distribusi OA Lutut Berdasarkan Indeks Masa Tubuh (IMT)}

Obesitas merupakan salah satu faktor risiko yang berperan sebagai faktor risiko OA lutut. Pada keadaan normal, gaya berat badan akan melalui medial sendi lutut dan akan diimbangi oleh otot-otot paha bagian lateral sehingga resultannya akan jatuh pada bagian sentral sendi lutut. Sedangkan pada keadaan obesitas resultan tersebut akan bergeser ke medial sehingga beban yang diterima sendi lutut akan tidak seimbang karena bergesernya titik tumpu badan dan menyebabkan terkikisnya tulang rawan. ${ }^{8}$

Hasil penelitian ini bertolak belakang dengan konsep teori dimana proporsi responden dengan OA lutut sebagian besar terjadi pada responden dengan IMT kurus - normal (59.2\%) dimana sebanyak 64.4\% responden dengan IMT kurus-normal menderita OA lutut. Angka ini sedikit lebih besar daripada proporsi responden dengan IMT kelebihan berat badankegemukan yang menderita OA lutut (60.6\%). Beberapa penelitian mengungkapkan hasil yang berbeda-beda, pada penelitian yang dilakukan di Desa Serampingan, Tabanan sebanyak $100 \%$ sampel penelitian yang mengalami OA memiliki IMT kurus - normal. Namun 
penelitian Wahyuningsih NAS di Kecamatan Jebres, Surakarta menyatakan bahwa lansia dengan IMT kelebihan berat badan memiliki risiko terjadinya OA 4,9 kali lebih besar daripada lansia dengan IMT normal. ${ }^{3,8}$ Sedangkan penelitian Koentjoro SL di Rumah Sakit Dr. Kariadi Semarang menyatakan tidak ada hubungan yang bermakna antara IMT dengan derajat OA lutut. $^{9}$

Obesitas merupakan faktor risiko OA Lutut namun bukan satu-satunya faktor yang berpengaruh. Berdasarkan profil Puskesmas Susut I, pola konsumsi penduduk di Desa Susut atau kecenderungan untuk mengkonsumsi makanan biasanya akan dipengaruhi oleh tingkat pendapatan, selera dan lingkungan. Tingkat pendapatan penduduk di wilayah kerja Puskesmas Susut I yang mayoritas penduduknya adalah petani memiliki penghasilan yang tidak tetap dan tidak dapat ditentukan sehingga hal ini mempengaruhi pola konsumsi mereka sehari-hari. Obesitas dan kelainan metabolik bukan merupakan tren penyakit di daerah ini karena karakteristik penduduknya sehingga mungkin obesitas bukan menjadi faktor risiko utama OA lutut di daerah ini. $^{7}$

\section{Distribusi OA Lutut Berdasarkan Riwayat Beban Kerja}

Berdasarkan riwayat beban kerja, mayoritas penderita $O A$ terjadi pada responden dengan riwayat beban kerja sedang - berat (71.4\%) dimana sebesar $67.3 \%$ responden dengan beban kerja sedang - berat menderita OA lutut. Hasil ini sejalan dengan hasil penelitian di Desa Serampingan, Tabanan dimana 98.2\% penderita OA merupakan responden yang riwayat pekerjaan dan kesehariannya dengan beban pekerjaan yang berat.

Pada penelitian Toivanen juga didapatkan hubungan antara meningkatnya beban kerja seseorang dengan risiko terjadinya OA dimana seseorang dengan beban kerja berat mengalami peningkatan risiko terjadinya OA hampir sebesar 7 kali. Dinyatakan pula bahwa beban pekerjaan yang ringan tidak signifikan pengaruhnya terhadap terjadinya OA. ${ }^{3,4}$ Berdasarkan hasil di atas, edukasi serta intervensi yang dilakukan perlu menyasar kelompok penduduk yang terutama memiliki beban pekerjaan yang berat seperti pekerja fisik.

\section{Distribusi OA Lutut Berdasarkan Faktor Biomekanik}

Berdasarkan faktor biomekanika, distribusi kejadian OA lutut sebagian besar terjadi pada responden yang memiliki riwayat membawa beban saat bekerja (71.4\%) dengan perkiraan beban terbanyak < $25 \mathrm{~kg}$ (79.6\%), frekuensi kerja dengan beban terbanyak adalah $\geq 4 \mathrm{x}$ seminggu (53.1\%) dengan durasi kerja terbanyak adalah $\geq 17$ tahun (91.8\%) dan kondisi geografis saat bekerja terbanyak adalah naik turun dan bertangga (77.6\%).

Dilihat dari kecenderungan kejadian OA lutut menurut faktor risiko, $68.6 \%$ responden dengan riwayat membawa beban saat bekerja, $76.9 \%$ responden yang membawa beban $\geq 25 \mathrm{~kg}, 76.5 \%$ responden yang bekerja dengan beban $\geq 4 x$ dalam seminggu dan $64.3 \%$ responden yang bekerja $\geq 17$ tahun menderita OA lutut. Sedangkan berdasarkan kondisi geografis saat bekerja, $67.9 \%$ responden yang kondisi geografis kerjanya naikturun dan tangga menderita OA.

Penelitian yang dilakukan oleh Hadi S dkk di Bandungan menyatakan bahwa faktor risiko mekanik yang berpengaruh pada kejadian OA adalah membawa beban berat saat bekerja. Berat beban yang dapat menimbulkan OA lutut adalah beban lebih dari $50 \mathrm{lbs}$ atau sekitar $25 \mathrm{~kg}$ (1 lbs = 453,592 gram) dengan masa kerja 17,14 tahun atau lebih serta frekuensi kerja dengan beban adalah 4 kali seminggu. Kondisi geografi yang berbukit pada daerah kerja dengan mengangkat beban juga merupakan faktor risiko yang mempunyai pengaruh besar. ${ }^{11}$ Namun penelitian yang dilakukan oleh Virgiyanti A. di Semarang menyimpulkan bahwa tidak terdapat perbedaan yang signifikan pada kelompok OA lutut dan kelompok non OA lutut terkait faktor risiko beban biomekanik.Hal ini mungkin diakibatkan oleh karena dalam kesehariannya, beban yang diangkat $(\mathrm{kg})$ antara kelompok OA dan kelompok non OA relatif sama dan diduga terdapat bias recall dimana responden tidak memberikan data yang sebenarnya. ${ }^{3,11}$

Berdasarkan riwayat cedera lutut, sebagian besar kejadian OA dialami oleh responden yang tidak pernah mengalami cedera lutut sebelumnya (87.8\%). Namun sebesar $75 \%$ responden yang pernah mengalami cedera lutu menderita OA. Penelitian di Universitas IOWA menyatakan bahwa $13.9 \%$ dari mereka yang pernah mengalami trauma lutut termasuk trauma pada meniskus, ligamentum, ataupun tulang pada dewasa muda berkembang menjadi OA lutut dan mereka yang tidak pernah mengalami trauma lutut hanya $6 \%$ yang menderita OA lutut. 


\section{KESIMPULAN DAN SARAN}

Dari hasil penelitian dan pembahasan, dapat disimpulkan hal-hal sebagai berikut:

1. Prevalensi Osteoartritis (OA) lutut pada kelompok usia lebih dari 50 tahun di wilayah kerja Puskesmas Susut I, Kecamatan Susut, Kabupaten Bangli pada bulan April 2014 adalah sebesar 62.8\%.

2. Berdasarkan karakteristik sosio-demografi, kejadian OA lutut lebih banyak dialami oleh kelompok usia 50-70 tahun (61.2\%), berjenis kelamin perempuan (57.1\%), dan memiliki pekerjaan fisik (petani, peternak, buruh dan ABRI) (65.3\%).

3. Dilihat dari faktor risiko, kejadian OA lutut lebih banyak terjadi pada responden dengan IMT kurusnormal (59.2\%), riwayat beban kerja sedang-berat (71.4\%) dengan faktor biomekanika antara lain responden dengan riwayat membawa beban saat bekerja (71.4\%) dimana perkiraan berat beban $<25$ $\mathrm{kg}$ (79.6\%), frekuensi bekerja dengan beban sebanyak $\geq 4$ kali/minggu (53.1\%) dan memiliki durasi kerja $\geq 17$ tahun (91.8\%), serta menempuh jalan naik, turun, bertangga saat bekerja (77.6\%). Kejadian OA lutut cenderung lebih banyak terjadi pada responden tanpa riwayat cedera lutut (87.8\%).

Berdasarkan simpulan tersebut, dapat dirumuskan saran sebagai berikut :

1. Perlu dilakukan penelitian yang lebih mendalam untuk mencari hubungan dari faktor risiko terhadap kejadian OA lutut di wilayah kerja Puskesmas Susut I dan dengan teknik penegakan diagnosis yang disertai dengan pemeriksaan penunjang.

2. Perlu diadakan tindak lanjut oleh pihak Puskesmas Susut I berupa mengefektifkan program kesehatan usila dalam menurunkan morbiditas dan menghindari disabilitas akibat OA lutut misalnya berupa senam lansia secara rutin setiap minggunya, Sserta perlu diadakan penyuluhan oleh tim promosi kesehatan mengenai OA lutut dan bagaimana cara pencegahannya kepada masyarakat yang at risk OA lutut misalnya masyarakat usia produktif.

\section{DAFTAR PUSTAKA}

1. Kementrian Kesehatan RI. Gambaran Kesehatan Lanjut Usia di Indonesia. Jakarta: Kementrian Kesehatan RI ; 2013. Hal. 2 (Buletin Jendela Data dan Informasi Kesehatan)
2. Soeroso J, Isbagio H, Kalim H, Broto R, Pramidiyo R. Osteoartritis. Dalam : Sudoyo AW, Setiyohadi B, Alwi I, Simadibrata M, Setiati S, editor. Buku Ajar Ilmu Penyakit Dalam. Edisi V. Jakarta: Interna Publishing; 2009. Hal. 2538-42

3. Dwipayana GA, Sawenda K, Krishnan D. Prevalensi dan Distribusi Osteoartritis Berdasarkan Karakteristik, Indeks Masa Tubuh, Riwayat Beban Pekerjaan, dan Faktor Biomekanik pada Penduduk Usia Lanjut di Desa Serampingan, Kecamatan Selemadeg Kabupaten Tabanan. Denpasar: Fakultas Kedokteran Universitas Udayana; 2012

4. Toivanen AT, Heliovaara M, Impivaara O, Arokoski JPA, Knekt P, Lauren $H$, dkk. Obesity, physically demanding work and traumatic knee injury are major risk factors for knee osteoarthritis-a population-based study with a follow-up of 22 years. Rheumatology 2009; 49

5. Andriyasa K, Putra TR. Korelasi Antara Derajat Beratnya Osteoarthritis Lutut dan Cartilage Oligomeric Matrix Protein Serum. Jurnal Penyakit Dalam 2012; 13 (1)

6. Arissa MI. Pola Distribusi Kasus Osteoartritis di RSU Dokter Soedarso Pontianak Periode 1 Januari 200831 Desember 2009. Pontianak: Fakultas Kedokteran Universitas Tanjungpura; 2012

7. Puskesmas Susut I. Profil UPT. Puskesmas Susut I Tahun 2013. Bangli: Puskesmas Susut I; 2013

8. Wahyuningsih NAS. Hubungan Obesitas dengan Osteoartritis Lutut pada Lansia di Kelurahan Puncangsawit Kecamatan Jebres Surakarta. Surakarta: Fakultas Kedokteran Universitas Sebelas Maret; 2009

9. Koentjoro SL. Hubungan Antara Indeks Masa Tubuh (IMT) dengan Derajat Osteoartritis Lutut Menurut Kellgren dan Lawrence. Semarang: Fakultas Kedokteran Universitas Diponegoro; 2010

10. Maharani PE. Faktor-Faktor Risiko Oasteoartritis Lutut. Semarang: Program Studi Magister Epidemiologi Program Pascasarjana Universitas Diponegoro; 2007

11. Virgiyanti A. Beban Biomekanik sebagai Faktor Risiko Terjadinya Osteoartritis Lutut. Semarang: Fakultas Kedokteran Universitas Diponegoro; 2006 